\title{
Foraging space of emperor penguins Aptenodytes forsteri in Antarctic shelf waters in winter
}

\author{
Barbara C. Wienecke*, Graham Robertson \\ Australian Antarctic Division, Channel Highway, Kingston, Tasmania 7050, Australia
}

\begin{abstract}
To determine the foraging space of emperor penguins Aptenodytes forsteri in winter, 12 females from Auster colony (13400 pairs) were equipped with satellite transmitters and time-depth recorders before departing on their $76 \pm 9 \mathrm{~d}$ winter (June to August) foraging trip. The females were also injected with tritiated water (HTO) to estimate food consumption, and non-instrumented females were stomach sampled upon return to the colony to determine their diet. The same data were collected in August/September from 3 males foraging after their 4 mo prenuptial and incubation fast. Both females and males foraged in pack-ice within $120 \mathrm{~km}$ of the colony along a relatively narrow band of the continental shelf in water depths ranging from 200 to $500 \mathrm{~m}$. Only rarely did penguins leave shelf waters to forage in deeper waters over the shelf break. The size of the general foraging area for females was about $11410 \mathrm{~km}^{2}$, but $50 \%$ of all foraging days were spent in only about $15 \%\left(1700 \mathrm{~km}^{2}\right)$ of the total foraging area. A female of average mass $\left(25 \mathrm{~kg}\right.$ ) hunted for about $6 \mathrm{~h} \mathrm{~d}^{-1}$, and consumed $1.8 \pm 0.3 \mathrm{~kg}$ of food per foraging day. This indicates that females from Auster consumed in winter about $1520 \mathrm{t}$, about half of which is likely to have been taken from an area measuring only $60 \times 28 \mathrm{~km}$. Males were active for about $10 \mathrm{~h} \mathrm{~d}^{1}$ and consumed about twice as much $\left(3.7 \pm 1.2 \mathrm{~kg} \mathrm{~d}^{-1}\right.$ for a $24 \mathrm{~kg}$ male) as the females during the early phase of brooding. The diet of females comprised $72 \%$ fish (by mass), $16 \%$ squid and $12 \%$ Antarctic krill Euphausia superba whereas that of the males comprised $53 \%$ fish, $2 \%$ squid and $43 \%$ krill. Most foraging dives of females $(81 \%)$ and males $(64 \%)$ were to $<200 \mathrm{~m}$ and lasted less about $3 \mathrm{~min}$. Males dived deep (>300 m) more frequently than females $(19.8 \%$ vs $0.1 \%$ ) but the number of dives per day was similar for both sexes ( $27 \pm 14$ for winter females, $31 \pm 15$ for brood-stage males). The small foraging area, diet composition and prey harvest rates of the females provide indirect evidence of the availability of penguin prey species in the pack-ice off Auster in winter.
\end{abstract}

KEY WORDS: Emperor penguin - Antarctic winter - Foraging area - Pack-ice - Prey occurrence

\section{INTRODUCTION}

The distribution and occurrence of prey species in Antarctic waters in winter may be assessed indirectly by examining the foraging performance of seabirds. The emperor penguin Aptenodytes forsteri is an excellent species on which to conduct this kind of research. Emperor penguins breed on fast-ice through the winter, forage in pack-ice (Kirkwood \& Robertson 1997a), are eclectic in their dietary preferences (e.g. Robertson et al. 1994) and, at 20 to $40 \mathrm{~kg}$, are large enough to transport instruments to sample the ocean. These features, combined with an extended $(-77 \mathrm{~d})$ female postlaying foraging excursion and the likelihood that

•E-mail: barbar_wie@antdiv.gov.au instrument-bearing females will return to the colony at hatching, makes female emperor penguins ideal birds to gather information about pack-ice waters in winter (see Ancel et al. 1992).

To date, only Kirkwood \& Robertson (1997a) have examined the foraging performance of female emperor penguins in winter (May to July), all other foraging studies (e.g. Ancel et al. 1992, Kooyman \& Kooyman 1995, Robertson \& Newgrain 1996) having been conducted during chick rearing (July to December). Kirkwood \& Robertson (1997a) studied in detail the diving patterns and feeding rates of female emperor penguins during winter but had limited success linking the penguins' feeding to precise locations and foraging areas which is essential if the penguins are to provide a measure of prey occurrence. 
In this study we were able to establish the size of the foraging areas of female emperor penguins and the distances they travelled in winter (June/July). We complemented this work with estimates of their diet composition, prey harvest rates and diving depths, and related this information to the bathymetry and the nature and extent of the sea-ice. This provided insights into the distribution and occurrence of penguin prey species in winter. Similar measurements were obtained from a small number of males foraging during the brood stage of the breeding cycle (July to September).

\section{MATERIALS AND METHODS}

Study colony, penguins and weather. The study was conducted at the Auster emperor penguin colony $\left(67^{\circ} 23^{\prime} \mathrm{S}, 64^{\circ} 04^{\prime} \mathrm{E}_{\text {; }}\right.$ see descriptions by Budd 1961 and Robertson 1992), between May and October 1994. Auster (about 13400 pairs) is situated on fast sea-ice $55 \mathrm{~km}$ east of Australia's Mawson station. The study spanned the period from egg laying (May) to late chick brooding (September/October). Over this period environmental conditions changed markedly. In mid June, the colony was in darkness for up to $21 \mathrm{~h} \mathrm{~d}^{-1}$ (twilight prevailed for the remaining $3 \mathrm{~h} \mathrm{~d}^{-1}$ ) and ambient temperatures often fell as low as $-36^{\circ} \mathrm{C}$ (maximal temperature in June $-29^{\circ} \mathrm{C}$ ). By late chick brooding, day length had nearly doubled and ambient temperatures often reached $\sim 25^{\circ} \mathrm{C}$. In May, when the study commenced, the ice-edge lay about $60 \mathrm{~km}$ north of the colony (deduced from NOAA-12 satellite images).

Measuring feeding space. The 3-dimensional foraging space of the penguins was measured by deployment, on the same birds, of satellite transmitters (platform transmitter terminals; PTTs) and time-depth recorders (TDRs). The PTTs recorded the penguins horizontal movements and locations of foraging areas and the TDRs recorded dive depth at known locations. We used seven ST- 6 and five ST-10 PTTs (Telonics, USA) weighing 290 and 257 g, respectively. The frontal areas of these PTTs were 18 and $15 \mathrm{~cm}^{2}$ (3 and $2.5 \%$ of the $590 \mathrm{~cm}^{2}$ cross-sectional area of a $24 \mathrm{~kg}$ penguin), respectively. The ST-6s transmitted continuously while the ST-10s were on a $23 \mathrm{~h}$ on $/ 25 \mathrm{~h}$ of $\mathrm{f}$ cycle. All PTTs transmitted at $90 \mathrm{~s}$ intervals. To measure dive depth we used seven Mk 5 (256 Kb, $68 \mathrm{~g}$, frontal area $\left.6 \mathrm{~cm}^{2}\right)$ TDRs and five Mk $6(512 \mathrm{~Kb}, 120 \mathrm{~g}$, frontal area $15 \mathrm{~cm}^{2}$; Wildlife Computers, USA) TDRs. Data were collected on a $7 \mathrm{~d}$ on $/ 13 \mathrm{~d}$ off protocol at $2 \mathrm{~s}$ intervals to maximise memory life, the dive-thresholds were set at $6 \mathrm{~m}$ and the internal clocks were set at Local Solar Time (GMT + $4 \mathrm{~h})$.
In late May, PTTs and TDRs were attached to 12 female penguins leaving Auster after laying on their winter foraging trip. Females were identified by external cloacal inspection: a reddish, distended, and often blood stained cloaca indicated that a female had recently laid. In early August, instruments on the first 3 females to return were redeployed on 3 males as they left the colony for their first foraging trip after incubation. A further 9 males were equipped with TDRs only. To minimise drag (Culik et al. 1994, see below) all instruments were attached to the feathers of the lower back, using Loctite $401^{\mathrm{TM}}$ and hose clamps. All penguins were breeding adults weighing 23.5 to $31.0 \mathrm{~kg}$ at the time of initial capture. At the end of their foraging trips penguins carrying instruments were caught either before they reached the colony or, if they had passed unnoticed, on their next excursion to sea.

Evaluation of instrument effect. Externally attached instruments increase the body drag of diving birds and may extend their foraging trips (Culik \& Wilson 1991). To assess the effects of the relatively bulky PTT/TDR combination on the foraging performance of the females during winter, we compared the foraging trip durations of the PTT/TDR-bearing penguins with the trip durations of 5 females equipped with radio transmitters only. The transmitters weighed $68 \mathrm{~g}$ and had a frontal area of $3 \mathrm{~cm}^{2} \quad<0.5 \%$ of the penguins' crosssectional area) and were expected to have minimal impact on the diving and swimming performance of the penguins.

Analysis of PTT and TDR data. ARGOS satellite records were processed with customised software of the Australian Antarctic Division. Satellite locations were classified according to the size of the error radius of the location and the number of signals received by the satellite during a pass. Error radii, which were calculated for positions based on at least 4 signals, were $350,500,1000$ and $>1000 \mathrm{~m}$ for class 3, 2, 1 and class 0 locations, respectively. Error radii were not calculated for class A and class B locations which were based on 3 and 2 signals, respectively; class $Z$ included signals for which the locations could not be determined. The assumed accuracy of the locations is thus based on the number of signals the satellite receives which in turn is influenced by the angle between transmitter and satellite, the amount of traffic on the receiving frequency and the activity of the penguin.

A class 3 location is not necessarily more accurate than a class $B$, but the probability of the penguin being at the location determined by a class 3 fix is higher than for a fix of lesser quality. For this reason we decided not to discard categorically all fixes <class 0 and used the parameter of 'maximal allowed speed' for the acceptance or rejection of locations. By this method all data points are assumed to be valid. To 
evaluate the accuracy of a given location, the speed of travel to the previous 2 and the next 2 locations are calculated from the point in question. The average speed is determined by taking the root mean square of the 4 travelling speeds and assigned to the location in question. The procedure is repeated from the previous 3 to the next 3 locations. Should the root mean square exceed a predetermined maximal speed the point with the highest speed is eliminated from the sample. This procedure is repeated until all speeds above the nominated maximal speed have been eliminated. We set the maximal speed at $15 \mathrm{~km} \mathrm{~h}^{-1}$, this being slightly higher than the $14.4 \mathrm{~km} \mathrm{~h}^{-1}$ estimated by Kooyman et al. (1992) of emperor penguins diving under the ice.

Maximal distances from Auster were measured in a straight line between the colony and the penguin's most distant position from Auster. Total travelling distances comprised the sum of all distances between locations deemed to be valid.

Data collected by the dive recorders were analysed following the dive classification in Kirkwood \& Robertson (1997a). Non-foraging dives were of short duration ( 2 to 30 s) and were characterised by smooth descents and ascents, and shallow maximal dive depths. Dives not fitting this description were assumed to be foraging dives. No distinction was made between search dives and feeding dives.

Diet composition and feeding rates. Stomach samples were collected using the water offloading technique of Wilson (1984) modified slightly (Robertson 1991) for emperor penguins. In late July, 20 non-instrumented females were flushed when they returned from their winter at sea. In mid-August, stomach samples were collected from 20 males returning from their first foraging trip after their winter fast. All penguins were weighed to $\pm 0.1 \mathrm{~kg}$ before stomach samples were collected and all penguins were flushed 2 to 3 times after which their stomachs were assumed to be empty.

The analysis of stomach samples followed Robertson et al. (1994) and Kirkwood \& Robertson (1997a). Of the total sample, $300 \mathrm{~g}$ subsamples were sorted for identifiable hard parts, such as fish otoliths and squid beaks. The size of fish and squid were estimated using the equations of Williams \& McEldowney (1990) and Lu \& Williams (1994). Only lower beaks were used in the identification of squid (Clarke 1986).

Feeding rates were estimated from dietary water fluxes using tritiated water $\left(\mathrm{HTO},{ }^{3} \mathrm{H}_{2} \mathrm{O}\right.$; Nagy \& Costa $1980)$ as a tracer following the field and laboratory protocols described by Robertson \& Newgrain (1996). Briefly, in May, 25 females, including the 12 females instrumented (i.e. instrument-bearing females), leaving the colony after laying were injected intramuscularly with $1.5 \mathrm{ml}$ of distilled water containing $60 \mathrm{mCi}$ HTO. In August, $1 \mathrm{ml}$ of water with $40 \mathrm{mCi} \mathrm{HTO}$ was injected into the pectoral muscles of 25 males, including the 3 instrumented penguins. After injection and before release, the penguins were weighed and restrained in an enclosure on the sea-ice for $2 \mathrm{~h}$ to allow HTO to equilibrate with body water pools. Total body water contents were estimated from a $2 \mathrm{ml}$ blood sample taken after isotope equilibration. On return from their foraging trips penguins were recaptured, reweighed and a second blood sample taken. Only samples with HTO levels at least 3 times above background levels were included in the analysis (Green \& Gales 1990; Appendix 1). Note, however, that to our knowledge there is no empirical evidence of the validity of the post-foraging HTO blood levels chosen for the analyses, and for this reason it would be prudent to consider the water influx estimates as provisional.

Water flux rates were estimated from the decline in specific activity of HTO in consecutive blood samples using Eq. (4) of Nagy \& Costa (1980). Influx rates were increased by $7 \%$ (an average of values in Robertson \& Newgrain 1996 and Kirkwood \& Robertson 1997a) to account for the degree to which the HTO method underestimates dietary water intake by emperor penguins. The estimates were then reduced by $2.4 \mathrm{ml} \mathrm{kg}^{-1}$ $\mathrm{d}^{-1}$ (Robertson \& Newgrain 1996) to account for incidental seawater intake by foraging penguins. Mass gains by penguins after HTO injection were assumed to be fat and the metabolic water $\left(1.07 \mathrm{ml} \mathrm{g}^{-1}\right.$; SchmidtNielsen 1975) released from this non-labelled fat was subtracted from each penguin's total water influx (see Kirkwood \& Robertson 1997a). In winter, snow consumption by penguins at the colony was rarely observed so we assumed snow consumption away from the colony was negligible (see Kirkwood \& Robertson $1997 \mathrm{~b})$.

Prey consumption rates were estimated by dividing water influxes by the dietary (free + metabolic) water content using the same water content values for fish, squid and krill described in Kirkwood \& Robertson (1997c). Prey intake rates were calculated per foraging day (transit days were excluded) since most penguins did not stop before reaching the ice-edge. For the penguins equipped with PTTs the number of transit days could be determined accurately and was subtracted from each bird's trip duration. For the penguins without transmitters, the mean number of transit days (17 d) of the PTT penguins was subtracted from the number of days the non-PTT birds spent away from the colony.

Statistics. Statistical significance was accepted at $p<$ 0.05. Comparisons between females and males were made with 2-tailed, unpaired Student's $t$-tests. F-ratio tests and arcsine transformations were used to normalise percentage data and homogenise their variances. Means are given \pm 1 standard deviation and goodness of fit was tested with $\chi^{2}$ analyses (Zar 1984). 


\section{RESULTS}

\section{Recapture success and instrument effect}

Three of the 12 winter females and 2 of the 3 PT'T males escaped recapture and made a second trip to sea. One of these females (F-6) made a third trip before her instrument was retrieved (Table 1). Thus, a total of 21 foraging trips (9 by winter females and 7 at the brood-stage, and 5 by brood-stage males) were recorded and overall 8235 and 674 valid locations were analysed for females and males, respectively.

Nine of the 12 winter females returned after 67 to $96 \mathrm{~d}$ (mean: $76 \pm 9 \mathrm{~d}$ ) at sea. By comparison, the females equipped only with radio transmitters arrived after 65 to $80 \mathrm{~d}$ (mean: $73 \pm 7 \mathrm{~d}$ ). Since the difference between the medians of these 2 groups was not significant $(U=22, p>0.05)$ we concluded that the PTTs had not measurably influenced the trip length of these penguins. The remaining 3 PTT females spent more than $100 \mathrm{~d}$ at sea. One of these females (F-11) exhibited behaviour initially similar to the group of 9 but did not return to the colony during 1994. Two females ( $F-1$ and F-7) travelled much further north and west than the other females. Because these last 2 penguins behaved differently in comparison to the other females, their travels were treated separately in the analysis of foraging areas.

\section{Changes in body mass}

Ten of the 12 winter females gained $3.3 \pm 1.4 \mathrm{~kg}$ (range: 2.2 to $5.6 \mathrm{~kg}$ ) while at sea, or $54.5 \pm 23.7 \mathrm{~g} \mathrm{~d}^{-1}$ (range: 19.2 to $93.3 \mathrm{~g} \mathrm{~d}^{-1}$ ). The males gained $3.4 \pm$ $3.0 \mathrm{~kg}$ (range: 0.3 to $9 \mathrm{~kg}$ ), or $181.9 \pm 152 \mathrm{~g} \mathrm{~d}^{-1}$ (range: 3.1 to $426.8 \mathrm{~g} \mathrm{~d}^{-1}$ ) on their fast-breaking foraging trips. Although about 1 to $2 \mathrm{~kg}$ of this added mass may have been intended for the chick (Robertson et al. 1994), most adults increased their body masses at sea. One male lost $1.6 \mathrm{~kg}$ while he was away from the colony and the 2 females that undertook unusually long journeys both lost $1.5 \mathrm{~kg}$, and were among those with the lowest initial body masses.

Table 1. Aptenodytes forsteri. Total and mean daily ( $(\mathrm{SD})$ distances travelled by winter female and brood-stage male emperor penguins equipped with PTTs (platform transmitter terminals) at Auster in the 1994 winter

\begin{tabular}{|c|c|c|c|c|c|}
\hline Penguin & $\begin{array}{l}\text { Foraging } \\
\text { trip }\end{array}$ & $\begin{array}{c}\text { Trip dates } \\
\text { (depart-return) }\end{array}$ & $\begin{array}{l}\text { Trip duration } \\
\text { (d) }\end{array}$ & $\begin{array}{c}\text { Distance } \\
\text { travelled }(\mathrm{km})\end{array}$ & $\begin{array}{l}\text { Maximal distance } \\
\text { from colony }(\mathrm{km})\end{array}$ \\
\hline \multicolumn{6}{|l|}{ Females } \\
\hline$F-1^{\circ}$ & 1 & $22 \mathrm{May}-7$ Oct & 138 & 4040 & 565 \\
\hline $\mathrm{F}-2$ & 1 & 21 May-29 Jul & 69 & 2330 & 124 \\
\hline$F-3$ & 1 & 20 May-5 Aug & 76 & 2950 & 147 \\
\hline$F-4$ & 1 & 21 May-29 Jul & 69 & 3190 & 144 \\
\hline F-5 & 1 & 26 May-1 Aug & 67 & 1640 & 144 \\
\hline F-6 & 1 & 24 May-13 Aug & 81 & 3515 & 135 \\
\hline$F-7^{a}$ & 1 & $26 \mathrm{May}^{2}-12 \mathrm{Sep}$ & 108 & 4940 & 524 \\
\hline$F-8$ & 1 & $25 \mathrm{May}-14$ Aug & 81 & 2835 & 118 \\
\hline$F-9$ & 1 & $26 \mathrm{May}-4 \mathrm{Aug}$ & 71 & 2635 & 111 \\
\hline$F-10$ & 1 & 26 May-6 Sep & 72 & 2540 & 187 \\
\hline $\mathrm{F}-11^{b}$ & 1 & 28 May-? & $149+$ & $6160+$ & 255 \\
\hline F-12 & 1 & 25 May-2 Sep & 96 & 1915 & 91 \\
\hline Mean $( \pm S D\}$ & & & $76( \pm 9)$ & $2617( \pm 595)$ & $133( \pm 27)$ \\
\hline$F-2$ & 2 & 18 Aug-4 Sep & 16 & 1430 & 88 \\
\hline$F-5$ & 2 & 3 Sep-19 Sep & 16 & 780 & 124 \\
\hline$F-6$ & 2 & 28 Aug-9 sep & 11 & 875 & 62 \\
\hline Mean $( \pm \mathrm{SD})$ & & & $14( \pm 3)$ & $1028( \pm 351)$ & $91( \pm 31)$ \\
\hline$F-6$ & 3 & $18 \mathrm{Sep}-10 \mathrm{Oct}$ & 22 & 1405 & 100 \\
\hline \multicolumn{6}{|l|}{ Males } \\
\hline M-1 & 1 & 7 Aug-4 Sep & 29 & 21.10 & 83 \\
\hline$M-2$ & 1 & 8 Aug-26 Aug & 19 & 1045 & 103 \\
\hline M-3 & 1 & 8 Aug-29 Aug & 21 & 1070 & 106 \\
\hline Mean $( \pm \mathrm{SD})$ & & & $23( \pm 5)$ & $1408( \pm 608)$ & $65( \pm 49)$ \\
\hline M-1 & 2 & $17 \mathrm{Sep}-9 \mathrm{Oct}$ & 22 & 905 & 80 \\
\hline$M-2$ & 2 & 2 Sep-23 Sep & 21 & 955 & 125 \\
\hline
\end{tabular}



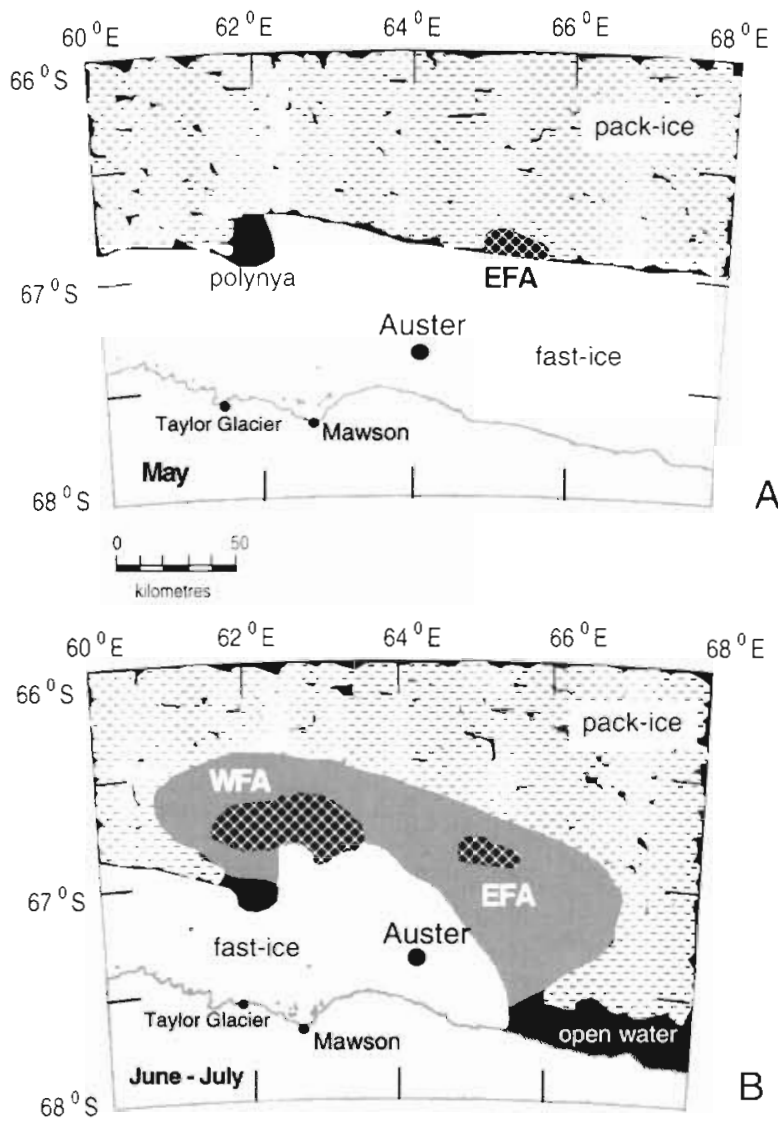

Fig. 1. Aptenodytes forsteri. Foraging areas used by female emperor penguins from Auster colony in (A) May and (B) June/July 1994. ( $\square$ ) General foraging area, ( foraging area (EFA) and western foraging area (WFA) where most overlap of penguin tracks occurred. In May, shortly after the females reached the ice-edge, only the EFA was used. The sea-ice east of Auster broke out in mid-June. ( $E$ ) Packice

\section{Foraging areas and travel distances by winter females}

On their departure from Auster in late May, 11 of the 12 winter females headed to an area of pack-ice northeast of the colony on the edge of the continental shelf (hereafter called the 'eastern foraging area'; Fig. 1A). The remaining female (F-9) travelled in a northwesterly direction towards the ice-edge. All females equipped with PTTs travelled for 7 to $11 \mathrm{~d}$ (mean: $8 \pm$ $3 \mathrm{~d}$ ) across about $70 \mathrm{~km}$ of fast-ice before reaching the ice-edge. At the end of their winter foraging trip, females travelled from the ice-edge to the colony in $5 \pm$ $2 \mathrm{~d}$ (range: 3 to $8 \mathrm{~d}$ ); while the females were at sea, the fast-ice broke out east of Auster and reduced the females' travelling distance to $50 \mathrm{~km}$ in late July (Fig. 2). The females were away from the colony for $76 \pm 9 \mathrm{~d}$ (range: 67 to $96 \mathrm{~d}$ ) of which $63 \pm 11 \mathrm{~d}$ were spent foraging.

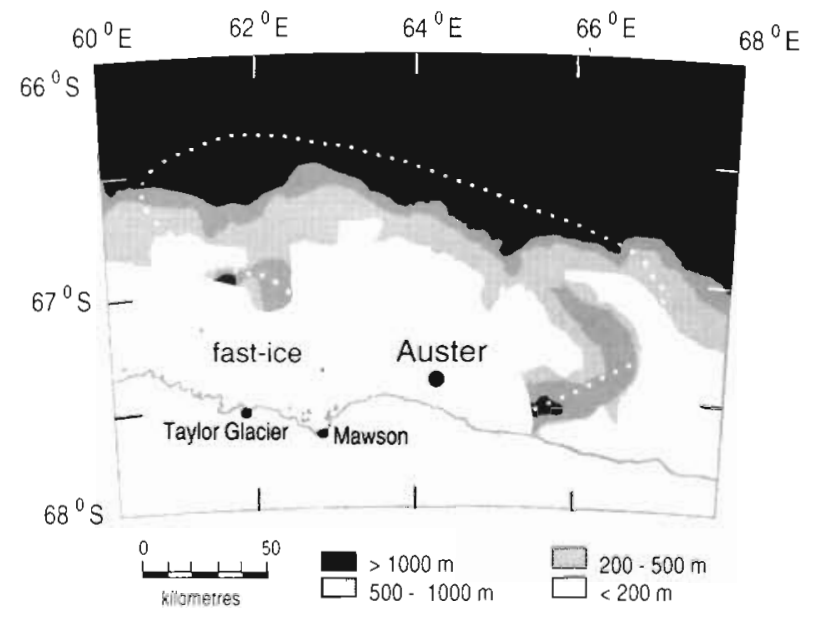

Fig. 2. Bathymetry of the Mawson coast and the extent of fastice in June 1994. The broken line represents the outline of the general foraging area of female emperor penguins shown in Fig. 1B

Eleven females foraged in the eastern foraging area just north of the ice-edge for $7 \pm 2.5 \mathrm{~d}$ (range: 3 to $10 \mathrm{~d}$ ) at the northern opening of a submarine canyon that cuts across the continental shelf east of Auster (Fig. 2). Here the overlap of individual foraging ranges was substantial and covered an area of about $420 \mathrm{~km}^{2}$ (Fig. 1A). Then 10 females headed west and 1 female (F-2) moved east. Female F-9, which left the colony after the others, also ventured east once she reached the ice-edge. In their time at sea the females moved mainly parallel to the shelf break, with comparatively little north-south movement.

Shortly after the females arrived at the ice-edge, the fast-ice about $50 \mathrm{~km}$ east of Auster broke out and exposed a large area of open water (Fig. 1B) which did not refreeze for the remainder of the season. Only 2 females moved east from their arrival point at the ice edge towards this open water while the others travelled west from the eastern foraging area concentrating their foraging activities in a second area of open pack-ice over the shelf (hereafter called the 'western foraging area', Fig. 1B). Of the total 635 foraging days at sea by all females combined, 327 (52\%) were spent in this western area, which extended in a relatively narrow band from $66^{\circ} 30^{\prime}$ to $67^{\circ} \mathrm{S}$ and from $61^{\circ}$ to $63^{\circ}$ $30^{\prime} \mathrm{E}$. The total foraging area of the females included about $11410 \mathrm{~km}^{2}$, but the 2 areas used intensively (see hatched areas in Fig. 1) by the females covered only about $1700 \mathrm{~km}^{2}$; this area formed an oval shape about $60 \times 28 \mathrm{~km}$ and represented about $15 \%$ of the total estimated foraging area. All females foraged over the continental shelf and slope in waters 200 to $500 \mathrm{~m}$ deep, and only occasionally did they venture into deeper $(1000 \mathrm{~m})$ water north of the shelf slope (Fig. 2). 


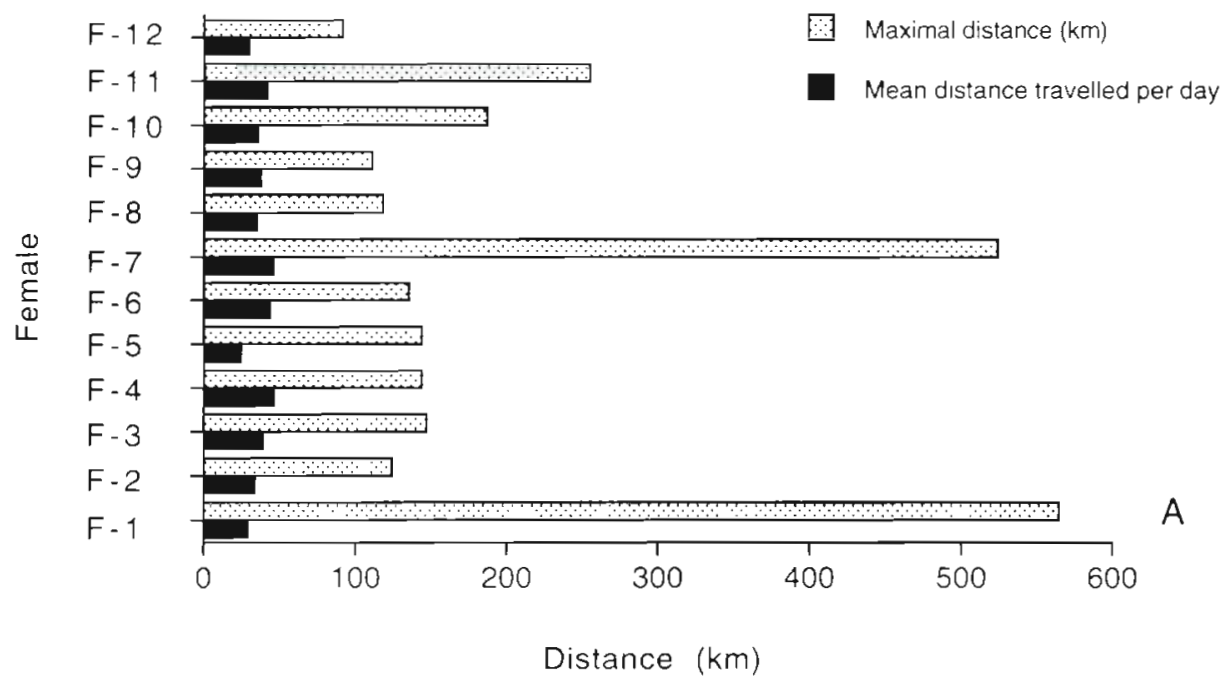

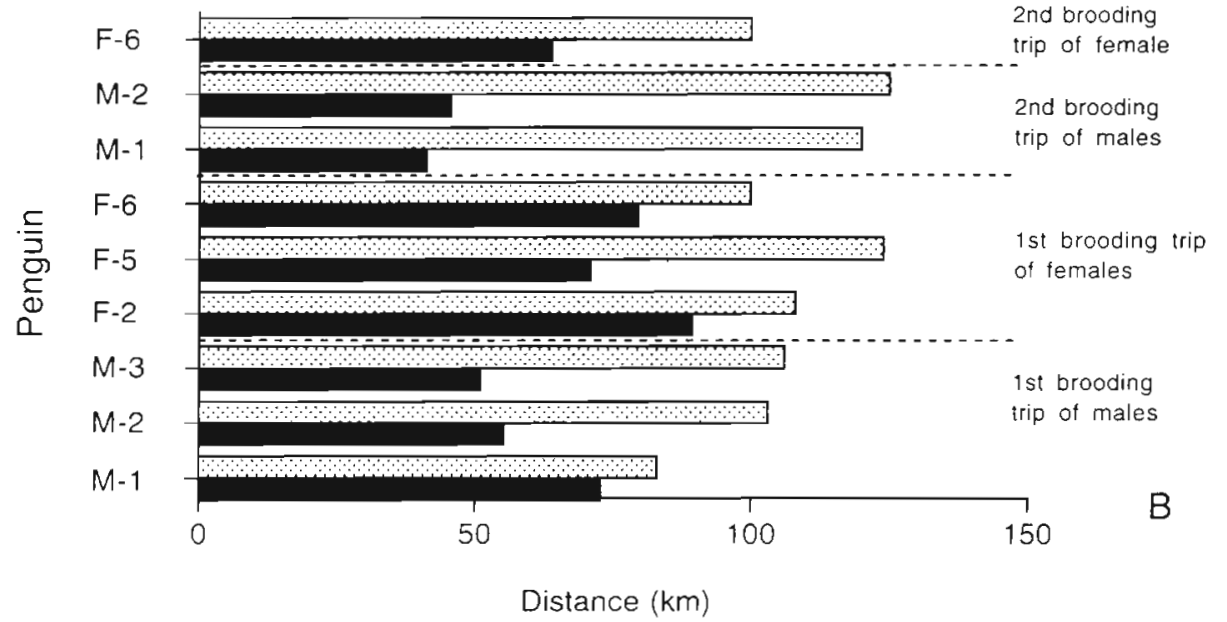

Fig. 3. Aptenodytes forsteri. Maximal distances and mean daily distances travelled by (A) winter females and (B) brood-stage females and male emperor penguins from Auster in 1994
Although they foraged in a relatively small area, the winter females travelled between 1640 and $3515 \mathrm{~km}$ (Table 1) in their $76 \mathrm{~d}$ away from the colony. Maximal distances from Auster ranged from 91 to $255 \mathrm{~km}$ (mean: $133 \pm 27 \mathrm{~km}$; Fig 3A) and travel speeds reached 9 to $26 \mathrm{~km} \mathrm{~d}^{-1}$ (mean: $17 \pm 6 \mathrm{~km} \mathrm{~d}^{-1}$ ). At the mean daily speed, a female at the maximal distance from Auster and travelling continuously could have returned to the colony in 6 to $15 \mathrm{~d}$.

\section{Foraging areas and travel distances during the brood stage}

On leaving Auster in August, the 3 satellite-tracked males travelled east (Fig. 4) and reached the ice-edge ( $50 \mathrm{~km}$ away) in 3 to $4 \mathrm{~d}$. They then foraged for 9 to $19 \mathrm{~d}$ in the eastern foraging area used by the females during winter. The males foraged further south over the shelf than did the winter females, although the males also foraged where the submarine canyon meets the shelf break east of Auster. One male foraged on the shelf on either side of the canyon, and occasionally in waters inside it.

The first and second brood-stage trips of the females lasted 11 to $22 \mathrm{~d}$, respectively, during which time they travelled $1028 \pm 351 \mathrm{~km}$ (range: 780 to $1430 \mathrm{~km}$ ). Trip durations by the males varied from 19 to $29 \mathrm{~d}$ for their first journey after incubation (Table 1, Fig. 3B). The 2 males that made a second trip left the colony for 22 and $21 \mathrm{~d}$. These males travelled 1045 and $2110 \mathrm{~km}$ at, on average, 14 and $17 \mathrm{~km} \mathrm{~d}^{-1}$ and 955 and $905 \mathrm{~km}$ at 18.5 and $19.2 \mathrm{~km} \mathrm{~d}^{-1}$ on their first and second trips, respectively. In August, their trips were, on average, a week longer than those of the females foraging at the same time (males $22 \pm 3 d_{i}$ females $14 \pm 3 \mathrm{~d}$ ). The males moved on average less than $99 \pm 18 \mathrm{~km}$ from the colony, equal to 4 to $7 \mathrm{~d}$ travelling time. 


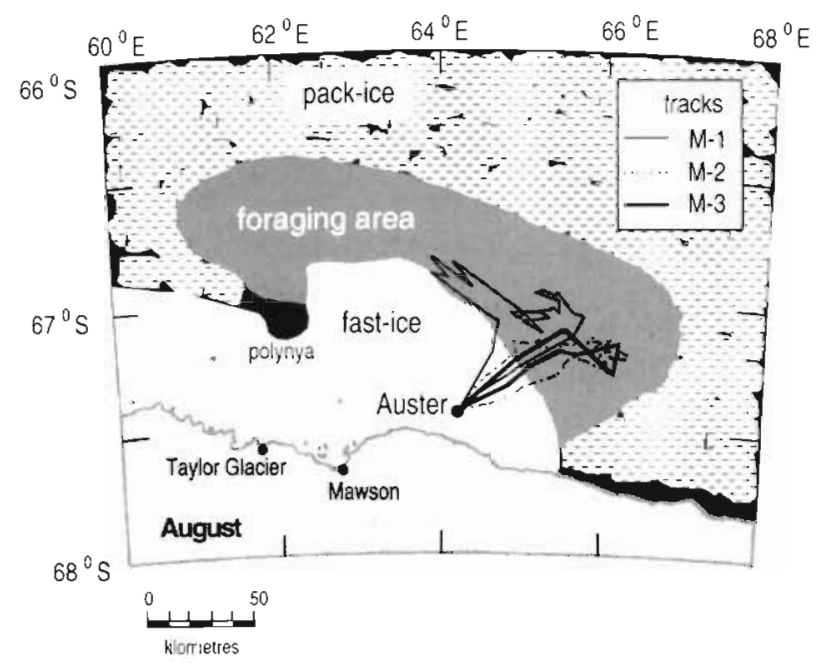

Fig. 4. Aptenodytes forsteri. Satellite tracks of 3 male emperor penguins from Auster on their fast-breaking foraging trips in August 1994. The foraging locations of the males overlapped the general foraging area used by the females in winter (May to July)

The 3 females (F-2, F-5 and F-6) that made a second brood-stage trip also foraged only in the eastern foraging area. The brooding stints between foraging trips of females F-2 and F-6 lasted 19 and 15 d, respectively. However, after her first brooding stint female F-5 remained for $32 \mathrm{~d}$ on the fast-ice at or near the colony before returning to sea. During this time she left Auster twice for 3 to $4 \mathrm{~d}$ and on both occasions ventured about $10 \mathrm{~km}$ south-west of the colony.

\section{Extended winter foraging trips}

The tracks of the 2 females ( $F-1$ and $F-7$ ) that travelled far from the colony are shown in Fig 5. Female F-1 travelled much further north than any other penguin in the study and reached her most northerly position at $62^{\circ} 41^{\prime} \mathrm{S}, 60^{\circ} 8^{\prime} \mathrm{E}$ ( $565 \mathrm{~km}$ from the colony) on 12 September, $112 \mathrm{~d}$ after departure. During her journey she rarely spent more than $2 \mathrm{~d}$ in one area. In $138 \mathrm{~d}$ at sea, she travelled more than $4000 \mathrm{~km}$ at an average of $29 \pm 11 \mathrm{~km} \mathrm{~d}^{-1}$.

Female F-7 travelled nearly $5000 \mathrm{~km}$ in $108 \mathrm{~d}$ at sea, and arrived at her most westerly position $\left(65^{\circ} 53^{\prime} \mathrm{S}\right.$, $52^{\circ} 57^{\prime} \mathrm{E}$ ) on $24 \mathrm{July}, 30 \mathrm{~d}$ after leaving Auster. Initially, she spent $8 \mathrm{~d}$ in the eastern foraging area where most other females foraged before beginning her journey west. For $18 \mathrm{~d}$ she moved through the pack-ice 20 to $25 \mathrm{~km}$ north of the ice-edge until she reached about $54^{\circ} \mathrm{E}$ ( $500 \mathrm{~km}$ from Auster) where she remained for 3 wk. On July 21, she returned to the ice-edge and travelled south until early August, then east to Auster.

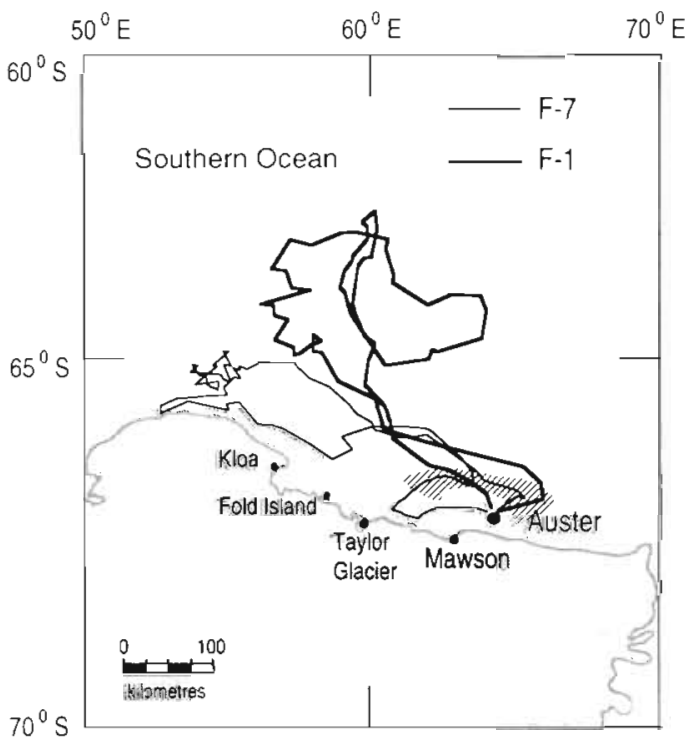

Fig. 5. Aptenodytes forsteri. Satellite tracks of females F-1 and F-7 from Auster colony that undertook extended winter foraging trips in 1994. The shaded area shows the general foraging area of 10 other tracked females (Fig. 1)

\section{Diving behaviour}

The TDRs on the winter females sampled for 27 to $54 \%$ of the trip durations before the memories were exhausted; those on the males recorded for the entire trip durations. With the TDRs on the 12 satellitetracked females 1 only recorded for $4 \mathrm{~d}$ and 3 of the 12 instruments deployed on males failed to record data. Consequently, data from 11 females and 9 males were available, comprising a total of 34406 dives (24948 and 9458 of females and males, respectively). Of these, $41 \%$ (or 13967 ) were travel dives (10890 or $44 \%$ for females and 3077 or $33 \%$ for males), the remainder ( $59 \%$ ) being foraging dives. With respect to foraging dives, both females and males frequently dived to $<50 \mathrm{~m}$ (females $58 \%$, males $51 \%$ ). However, males not only dived deeper than females (maximum depth reached: 444 vs $372 \mathrm{~m}$ ), they did so more frequently: 1 and $9 \%$ of dives of females and males, respectively, were to depths of $>300 \mathrm{~m}$. The mean maximal dive depths did not differ between the genders (females $211 \mathrm{~m}$, males $289 \mathrm{~m} ; t_{18}=0.24, \mathrm{p}>0.05$ ). The differences in the distribution of dive depths were also not significant $\left(t_{14}=0.55, \mathrm{p}>0.5\right)$.

The winter females made $27 \pm 14$ dives $d^{-1}$ and brood-stage males made $31 \pm 15$ dives $d^{-1}$; these differences were not statistically significant $\left(t_{18}=1.4, \mathrm{p}>\right.$ 0.05). Differences between the genders did, however, exist in other aspects of their foraging behaviour (Fig. 6). For $81 \%$ of their foraging dives females dived to between 10 and $200 \mathrm{~m}$ while males performed only 


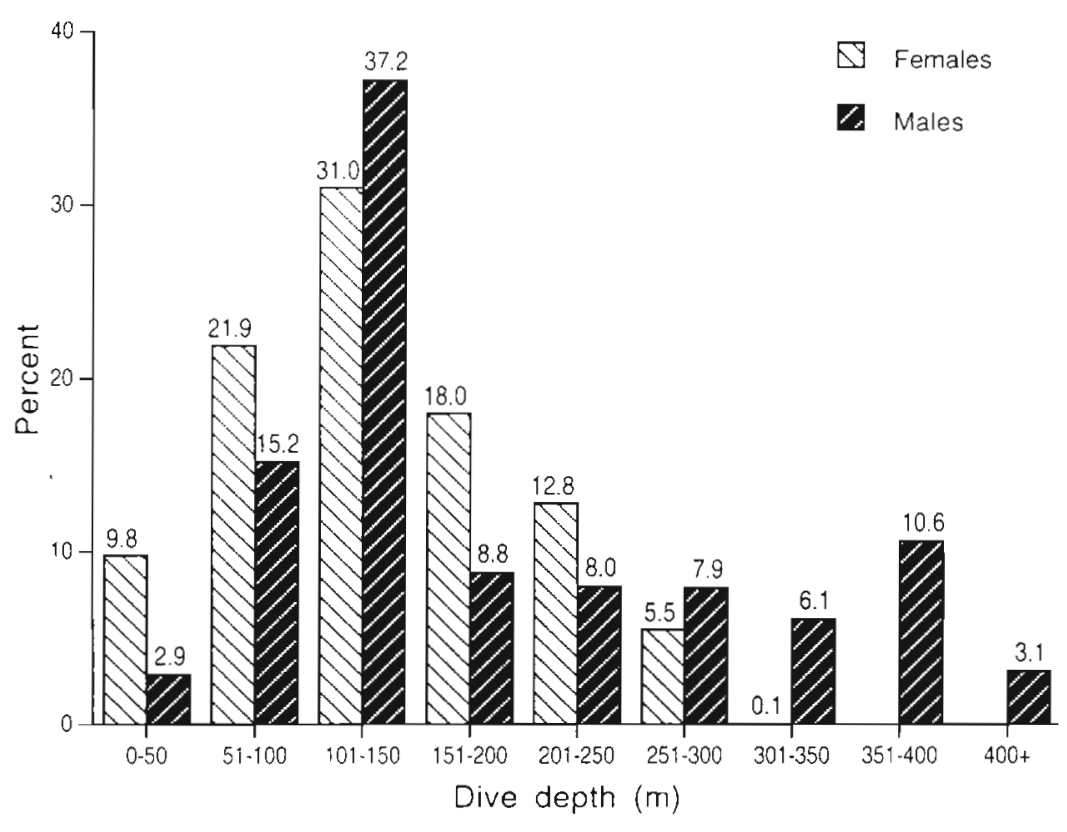

Fig. 6. Aptenodytes forsteri. Percentage distribution of maximal foraging dive depths (in $50 \mathrm{~m}$ increments) recorded by winter female and brood-stage male emperor penguins from Auster in 1994. Actual percentages are given above the bars
$64 \%$ of their dives in this depth range. Moreover, $31 \%$ of dives by females were between 150 and $250 \mathrm{~m}$ and only $6 \%$ exceeded $250 \mathrm{~m}$, whereas for males the percentages were 17 and $28 \%$, respectively.

In winter, females spent $5.1 \pm 0.6 \mathrm{~h}$ $\mathrm{d}^{-1}$ (range: 3.9 to $5.8 \mathrm{~h} \mathrm{~d}^{-1}$ ) in the water, $90 \%$ of which occurred from 09:00 to 15:00 h solar time. In contrast, males dived for $7.7 \pm 0.8 \mathrm{~h} \mathrm{~d}^{-1}$ (range: 6.1 to $8.5 \mathrm{~h} \mathrm{~d}^{-1}$ ) and $87 \%$ these dives occurred from 08:30 to $19: 00 \mathrm{~h}$. The differences in length of diving days were significant $\left(F_{1,17}=58.14, \mathrm{p}<0.01\right)$.

The simultaneous deployment of dive recorders and satellite trackers enabled the dive locations to be matched with the regional bathymetry. Fig. 7 shows representative examples of the dive profiles of a female and a male emperor penguin. Female F-2 (Fig. 7A) left Auster for the ice edge on 21. May and spent the first $2 \mathrm{~d}$ diving to $<100 \mathrm{~m}$ or near $150 \mathrm{~m}$ while still on the fast-ice; the water depth in
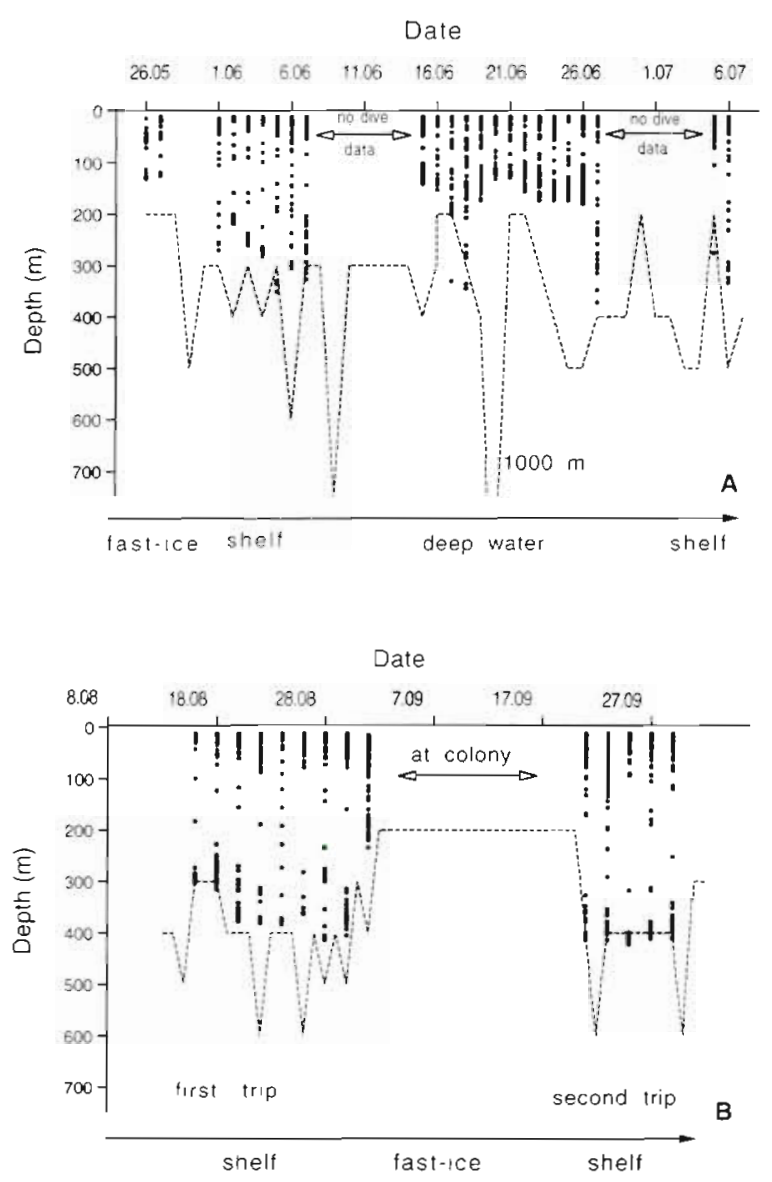

this area was about $200 \mathrm{~m}$. On 1 June, she reached the ice-edge over the continental shelf, and dived deeply $(300 \mathrm{~m})$, possibly to the sea floor, for several days, after which time the recorder switched off. In mid-June, she foraged over the shelf in water ranging to a depth of $1000 \mathrm{~m}$ but, apart from the occasional foray in excess of $300 \mathrm{~m}$, dived to $200 \mathrm{~m}$ or less. Hence the depth of the water may have influenced her diving depth. In the early, but not in the later, stages of her trip, this female tended to avoid the middle depths of her dive range, and dived mainly to $<100 \mathrm{~m}$ or $>200 \mathrm{~m}$.

Fig. $7 \mathrm{~B}$ shows an example of the dive patterns of male $M-1$ recorded on his fast-breaking trip (following hatching) and on part of his second brood-stage trip. This male dived only in water over the shelf at the periphery of the canyon east of Auster where the water

Fig. 7 Aptenodytes forsteri. Examples of diving profiles of (A) a female and (B) a male emperor penguin from Auster in 1994. (•) Maximal dive depths for individual dives; dashed line shows depth of the ocean floor. The TDR (time-depth recorder) on the female was duty cycled, hence there are gaps in the recording. For the male, dives were recorded for 2 consecutive foraging trips. The depth of the ocean floor is the depth of the location where the birds forage at local noon. Because of the steepness of the continental slope the penguins could have encountered great changes in water depths during a single foraging day. This explains why some dives appear deeper than the ocean floor. Dates appear as day.month 
depth ranged to $400 \mathrm{~m}$. He probably reached the ocean bed on many dives. On both excursions this male dived mostly to $<100 \mathrm{~m}$ and $>250 \mathrm{~m}$ exhibiting a similar behaviour as described for the female above

Mean dive durations for females and males were $3.2 \pm 0.5 \mathrm{~min}$ and $4.1 \pm 0.5 \mathrm{~min}$, respectively, and were not significantly different (Student's $t_{10}=35.17, \mathrm{p}<$ 0.05 ). The maximal dive time achieved by a female was $15.5 \mathrm{~min}$; the longest dive of a male lasted $21.3 \mathrm{~min}$.

\section{Prey composition}

The commonest prey item taken by both females and males was krill Euphausia superba (Table 2). However, only 5 of the 20 samples taken from females contained krill compared to 16 samples collected from males. By mass, the contribution of krill was exceeded by that of fish, which occurred in the majority of samples of females and males ( $n=20$ for both sexes). Five species of squid were identified, of which Psychroteuthis glacialis occurred most commonly in the diet samples of females ( 7 of 20 samples). Because of the duration of the winter foraging trips of the females this diet composition may be representative for the last stages of the foraging trip only.

The most common fish in the diet was Antarctic silverfish Pleuragramma antarcticum. Of the 245 otoliths and 54 jaws collected, only 17 and 42, respectively, were intact enough to allow estimates of standard lengths and masses. All otoliths and 41 jaws were identified as P. antarcticum; a single jaw of Trematomus newnesi was found. Since the estimates of standard length and mass based on otolith measurements differed from those based on jaw length, we assumed the otoliths and jaws in samples were from different individuals Ipresumably small otoliths eroded at a disproportionate rate to small jaws (e.g Suter \& Morel 1996, van Heezik \& Seddon 1989)]. The medians for length and mass of the silverfish consumed by female emperor penguins obtained from otoliths were $159 \mathrm{~mm}$ (range: 126 to $173 \mathrm{~mm}$ ) and $106 \mathrm{~g}$ (range: 84 to $115 \mathrm{~g}$ ), respectively; estimates from jaws gave a median length of $86 \mathrm{~mm}$ (range: 54 to $101 \mathrm{~mm}$ ) with a mass of $57 \mathrm{~g}$ (range: 36 to $67 \mathrm{~g}$ ). For males, the equivalent estimates were $147 \mathrm{~mm}$ (range: 104 to $159 \mathrm{~mm}$ ) and $98 \mathrm{~g}$ (range 69 to $105 \mathrm{~g}$ ) from otoliths, and $71 \mathrm{~mm}$ (range: 54 to $107 \mathrm{~mm}$ ) and $47 \mathrm{~g}$ (range: 36 to $71 \mathrm{~g}$ ) from jaws.

Overall, the mean length of silverfish in the diet of the winter females was $77 \pm 18 \mathrm{~mm}$ (mass: $51 \mathrm{~g}$ ) and that for the brood-stage males was $73 \pm 13 \mathrm{~mm}$ (mass: $48 \mathrm{~g}$ ): thus the penguins consumed juvenile silverfish only (Gon \& Heemstra 1990).

The squid Psychroteuthis glacialis occurred most commonly in the samples of females. Only 2 beaks, both of $P$. glacialis, were sufficiently intact to obtain

Table 2. Aptenodytes forsteri. Prey composition of 20 female and 20 male emperor penguins expressed as the number of samples containing prey items, number of items found in all samples and masses of prey items in samples

\begin{tabular}{|c|c|c|c|c|c|c|}
\hline Prey taxon & $\begin{array}{l}\text { Samples } \\
\text { with prey }\end{array}$ & $\begin{array}{l}\text { Females } \\
\text { Number of } \\
\text { items }(\%)\end{array}$ & $\begin{array}{c}\text { Mass }(g) \\
(\%)\end{array}$ & $\begin{array}{c}\text { Samples } \\
\text { with prey }\end{array}$ & $\begin{array}{c}\text { Males } \\
\text { Number of } \\
\text { items }(\%)\end{array}$ & $\begin{array}{c}\text { Mass }(g) \\
(\%)\end{array}$ \\
\hline \multicolumn{7}{|l|}{ Fish } \\
\hline \multicolumn{7}{|l|}{ Nototheniidae } \\
\hline Pleuragramma antarcticum & 16 & $34(24.8)$ & 146 & 18 & $53(10.6)$ & 277 \\
\hline Trematomus newnesi & 1 & $1(0.7)$ & 87 & 1 & $1(0.2)$ & 87 \\
\hline Trematomus sp. & 1 & $2(1.4)$ & 174 & 1 & $1(0.2)$ & 87 \\
\hline \multicolumn{7}{|l|}{ Paralepididae } \\
\hline Notolepis coatsi & - & - & & 1 & $2(0.4)$ & 20 \\
\hline \multicolumn{7}{|l|}{ Channichthyidae } \\
\hline Channichthyid sp. & 1 & $1(0.7)$ & 87 & 1 & $1(0.2)$ & 87 \\
\hline Unıdentified & 2 & $5(3.6)$ & 50 & 2 & $2(0.4)$ & 20 \\
\hline Total fish & & $43(20)$ & $544(72)$ & & $62(8)$ & $528(53)$ \\
\hline \multicolumn{7}{|l|}{ Squid } \\
\hline Psychroteuthis glacialis & 7 & $15(10.9)$ & 122 & 2 & $2(0.4)$ & 18 \\
\hline Alluroteuthis antarcticus & 3 & $9(5.8)$ & & - & - & \\
\hline Gonatus antarcticus & 1 & $1(0.7)$ & & - & - & \\
\hline Moroteuthis knipovitchi & - & - & & 1 & $1(0.2)$ & \\
\hline Kondakovia longimania & - & - & & 2 & $2(0.4)$ & \\
\hline Total squid & & $25(11)$ & $122(16)$ & & $5(0.1)$ & $18(2)$ \\
\hline \multicolumn{7}{|l|}{ Krill } \\
\hline Euphausia superba & 5 & 150 & 90 & 16 & 688 & 413 \\
\hline Total krill & & $150(69)$ & $90(12)$ & 16 & $688(92)$ & $413(43)$ \\
\hline Total number of items/mass & & 218 & 756 & & 752 & 959 \\
\hline
\end{tabular}


Table 3. Aptenodytes forsteri. Mean masses, trip durations, water influx and feeding rates of female and male emperor penguins from Auster in 1994. At-sea figures are based on foraging days oniy (i.e. trip duration minus the number of days of travel across the sea-ice). PTTs: platform transmitter terminals

\begin{tabular}{|c|c|c|c|c|c|c|c|c|c|c|}
\hline Penguins & $\mathrm{n}$ & $\begin{array}{c}\text { Mass on } \\
\text { departure } \\
(\mathrm{kg})\end{array}$ & $\begin{array}{c}\text { Mass } \\
\text { gained } \\
(\mathrm{kg})\end{array}$ & $\begin{array}{l}\text { Trip } \\
\text { duration } \\
\text { (d) }\end{array}$ & $\begin{array}{c}\text { Foraging } \\
\text { days } \\
(n)\end{array}$ & $n$ & $\begin{array}{r}\text { Water } \\
\text { (ml kg } \\
\text { Overall }\end{array}$ & $\begin{array}{l}\text { influx } \\
\left.{ }^{-1} \mathrm{~d}^{-1}\right) \\
\text { Per forag- } \\
\text { ing day }\end{array}$ & $\begin{array}{r}\text { Foragi } \\
\text { (g kg } \\
\text { Overall }\end{array}$ & 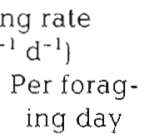 \\
\hline \multicolumn{11}{|l|}{ May-July } \\
\hline Females with PTTs & 9 & $\begin{array}{c}25.5 \\
( \pm 2.5)\end{array}$ & $\begin{array}{c}3.3 \\
( \pm 1.4)\end{array}$ & $\begin{array}{c}76 \\
( \pm 9)\end{array}$ & $\begin{array}{c}62 \\
( \pm 11)\end{array}$ & 8 & $\begin{array}{l}47.9 \\
( \pm 6.3)\end{array}$ & $\begin{array}{c}56.8 \\
( \pm 8.2)\end{array}$ & $\begin{array}{c}55.4 \\
( \pm 7.3)\end{array}$ & $\begin{array}{c}65.6 \\
( \pm 9.5)\end{array}$ \\
\hline Females without PTTs & 5 & $\begin{array}{c}25.1 \\
( \pm 2.4)\end{array}$ & $\begin{array}{c}4.8 \\
( \pm 0.8)\end{array}$ & $\begin{array}{l}79 \\
( \pm 3)\end{array}$ & $\begin{array}{l}65 \\
( \pm 2)\end{array}$ & 4 & $\begin{array}{l}45.3 \\
( \pm 3.2)\end{array}$ & $\begin{array}{c}53.2 \\
( \pm 3.0)\end{array}$ & $\begin{array}{c}52.3 \\
( \pm 3.7)\end{array}$ & $\begin{array}{c}61.5 \\
( \pm 3.5)\end{array}$ \\
\hline All females & 14 & $\begin{array}{c}25.3 \\
( \pm 2.4)\end{array}$ & $\begin{array}{c}3.7 \\
( \pm 1.4)\end{array}$ & $\begin{array}{c}77 \\
( \pm 8)\end{array}$ & $\begin{array}{l}63 \\
( \pm 9)\end{array}$ & 12 & $\begin{array}{l}47.3 \\
( \pm 5.5)\end{array}$ & $\begin{array}{c}55.7 \\
( \pm 7.0)\end{array}$ & $\begin{array}{c}54.6 \\
( \pm 6.3)\end{array}$ & $\begin{array}{c}64.3 \\
( \pm 8.0)\end{array}$ \\
\hline $\begin{array}{l}\text { August } \\
\text { Males }\end{array}$ & 13 & $\begin{array}{r}23.6^{\mathrm{a}} \\
( \pm 0.8)\end{array}$ & $\begin{array}{c}3.4 \\
( \pm 3.2)\end{array}$ & $\begin{array}{c}22 \\
( \pm 9)\end{array}$ & $\begin{array}{l}17 \\
( \pm 6)\end{array}$ & 11 & $\begin{array}{c}97.4 \\
( \pm 37.1)\end{array}$ & $\begin{array}{c}123.8 \\
( \pm 35.1)\end{array}$ & $\begin{array}{c}112.5 \\
( \pm 42.8)\end{array}$ & $\begin{array}{c}143.0 \\
( \pm 40.6)\end{array}$ \\
\hline
\end{tabular}

accurate measurements which could be used to estimate the mass of the prey; these masses were 18 and $104 \mathrm{~g}$. Three females caught Alluroteuthis antarcticus, which was the second most common squid species in the samples of females. No male consumed this species of squid. Other squid species occurred in very small numbers in the diets of both females and males.

\section{Rates of food consumption}

Of the 25 winter female and 25 brood-stage male penguins injected with HTO, 16 females (including 9 instrumented birds) and 15 brood-stage males were recaptured and blood-sampled before they entered the colony after their first foraging trips. Since the water influx rates of instrumented and non-instrumented females were statistically indistinguishable $\left(t_{10}=0.45, \mathrm{p}>\right.$ $0.05)$, the data were pooled. Water influxes per foraging day averaged $55.7 \pm 7.0 \mathrm{ml} \mathrm{kg}^{-1} \mathrm{~d}^{-1}$ for the winter females and $123.8 \pm 35.1 \mathrm{ml} \mathrm{kg}^{-1} \mathrm{~d}^{-1}$ for the 11 brood-stage males (Table 3 ). While at sea in winter a female of average mass (25 kg) consumed $1.8 \pm 0.3 \mathrm{~kg} \mathrm{~d}^{-1}(64.3 \pm 8.0 \mathrm{~g}$ $\mathrm{kg}^{-1} \mathrm{~d}^{-1}$ ) while a male of the same mass ingested $3.7 \pm$ $1.2 \mathrm{~kg} \mathrm{~d}^{-1}\left(143.0 \pm 40.6 \mathrm{~g} \mathrm{~kg}^{-1} \mathrm{~d}^{-1}\right)$. Thus, a female consumed $109 \pm 14 \mathrm{~kg}$ during her $63 \mathrm{~d}$ foraging and a male ingested $61 \pm 17 \mathrm{~kg}$ on his fast-breaking foraging trip

\section{DISCUSSION}

\section{Effects of fast-ice extent on foraging activity}

Emperor penguins breed on fast-ice close to the Antarctic continent where the ice is most stable. This means that adults can raise their young with minimal risk of an ice breakout, which could drown their chicks. A disadvantage of this fast-ice breeding habit is that colonies often lie great distances from open water or pack-ice and a substantial part of each excursion to sea must be spent commuting, which takes time and energy. At Auster, the winter females departing for $76 \mathrm{~d}$ crossed about $70 \mathrm{~km}$ of fast-ice in $8 \mathrm{~d}$ and returned in $5 \mathrm{~d}$, while the males on a $22 \mathrm{~d}$ trip traversed about $50 \mathrm{~km}$ of ice in 3 to $4 \mathrm{~d}$ each way. Hence 17 and $32 \%$ of the foraging trips by females and males, respectively, were spent traversing ice. Thus, while providing the penguins with a stable platform for breeding, the fastice, by forming an exclusion zone over potential foraging waters, imposed a substantial temporal cost on the emperor penguins breeding at Auster.

The distance between colony and foraging grounds also bears an energetic cost to the penguins. While travelling the penguins must metabolise fat reserves to satisfy their energy requirements. The dive data indicated that of the 11 instrument-bearing females that returned to Auster only 1 used tide cracks en route to the ice-edge. Assuming locomotion costs $17.5 \mathrm{~J} \mathrm{~kg}^{1} \mathrm{~m}^{-1}$ (Dewasmes et al. 1980), maintenance metabolism at basal levels (3.2 $\mathrm{MJ} \mathrm{d}^{-1}$; Ancel et al. 1997) and $39.4 \mathrm{~kJ}$ per gram of fat metabolised (Groscolas et al. 1991), a $25.3 \mathrm{~kg}$ female (average mass of females leaving Auster) traversing $70 \mathrm{~km}$ of fast-ice in a straight line in $8 \mathrm{~d}$ would have expended about $9.8 \mathrm{MJ}$ (i.e. $17.5 \mathrm{~J} \times 8 \mathrm{~d}$ $\times 70 \mathrm{~km}$ ) commuting and $25.6 \mathrm{MJ}$ (i.e. $3.2 \mathrm{MJ} \mathrm{d}^{-1} \times 8 \mathrm{~d}$ ) for maintenance; this would require the use of about $1.4 \mathrm{~kg}$ of fat [i.e. $0.0394 \times(9.8 \mathrm{MJ}+25.6 \mathrm{MJ})]$, equiva lent to about $5.5 \%$ of mean female body mass. However, the females did not travel in a straight line between Auster and the ice-edge. The 7 females 
equipped with ST-6 PPTs, which ran continuously (see 'Materials and methods'), zig-zagged their way across the ice travelling, on average, $175 \mathrm{~km}$ (range: 126 to $239 \mathrm{~km}$ ) for the $70 \mathrm{~km}$ journey; the extra $105 \mathrm{~km}$ travelled would have depleted their energy reserves by a further $45 \mathrm{MJ}$, equivalent to another $1.0 \mathrm{~kg}$ of fat.

The trip to the ice-edge would also have depleted the energy reserves of the males, which left Auster at hatching averaging only $23.6 \mathrm{~kg}$. Using Ancel et al.'s (1997) mass-specific values for basal metabolism, Dewasmes et al.'s (1980) estimates for locomotion and the logic outlined above for the females, the $50 \mathrm{~km}, 3 \mathrm{~d}$ straight-line trip to the ice edge would have cost about $29 \mathrm{MJ}$, the equivalent of about $0.75 \mathrm{~kg}$ of fat. By these estimates both females and males would have reached the ice-edge, and commenced feeding, weighing 22 to $23 \mathrm{~kg}$, similar to the mass at which protein catabolism would be expected to commence (Groscolas 1990). Clearly, the treks to open water in winter were energetically costly for both male and female emperor penguins breeding at Auster.

\section{Extended winter travels}

Two (F-1 and F-7) of the 12 winter females travelled far beyond the common foraging ground of the other females. Female F-1 moved in large loops and travelled $565 \mathrm{~km}$ north of the colony. Fledgling emperors from Taylor Glacier colony $\left(67^{\circ} 28^{\prime} \mathrm{S}, 60^{\circ} 53^{\prime} \mathrm{E}_{;} 155 \mathrm{~km}\right.$ west of Auster) satellite tracked in the summer of 1995/1996 also travelled well north of the colony into oceanic waters (Robertson unpubl. data); it is possible that F-1 was a maiden breeder with a tendency to revisit the waters in which she foraged as a younger bird. Extended travels of fledgling emperor penguins have also been reported elsewhere (Kooyman et al. 1996).

The second female (F-7) reached $52^{\circ} \mathrm{E}$, some $520 \mathrm{~km}$ west of Auster, $56 \mathrm{~d}$ after she left the colony. On her way she passed the emperor penguin colonies at Taylor Glacier and Fold Island $\left(67^{\circ} 20^{\prime} \mathrm{S}, 59^{\circ} 23^{\prime} \mathrm{E}\right)$ before stopping about $220 \mathrm{~km}$ west of Kloa colony $\left(66^{\circ} 38^{\prime} \mathrm{S}\right.$, $\left.57^{\circ} 19^{\prime} \mathrm{E}\right)$. She remained at this most westerly destination for $3 \mathrm{~d}$ before commencing her return journey eastward. At about $54^{\circ} \mathrm{E}$, she foraged for several days in a relatively small area over the continental shelf (see Fig. 5). She then continued her eastward journey, initially across the fast-ice but later across the pack-ice, until she reached Auster after $108 \mathrm{~d}$ of absence. Her return included few, if any, intense foraging stints. It is possible that this female may have become 'attached' to penguins from the other colonies or that she may have been a young breeder experiencing difficulties in navigating or in the timing of her winter travels.

\section{Location and size of foraging areas in winter and early spring}

During winter, 10 of the 12 tracked females foraged intensively over the continental shelf in 200 to $500 \mathrm{~m}$ of water in a narrow band between the northern limit of the fast-ice and the continental shelf slope and nearby oceanic waters (see Fig. 2). This area measured $11410 \mathrm{~km}^{2}$, but $50 \%$ of foraging days were spent in only $15 \%$ of this area (the $1700 \mathrm{~km}^{2}$ eastern and western areas). The eastern site lay in pack-ice covered waters over a 500 to $1000 \mathrm{~m}$ canyon (flanked by 200 deep water) which traverses the shelf and opens into deep oceanic water, and the western area was flanked by a polynya (area of permanently open water to the south and lay over water ranging in depth from 200 to $500 \mathrm{~m}$; at both sites the bathymetry is relatively complex and water depths range from 200 to $>1000 \mathrm{~m}$ over a few kilometres. Clearly the eastern and western foraging areas are of major significance to emperor penguins at Auster and may be areas of upwelling and nutrient enrichment where prey are available and are predictably located close to the colony.

When the females reached the ice-edge in early June, the submarine canyon in the eastern foraging area lay under fast-ice but became potentially accessible to the penguins in mid-June when the fast-ice broke out about $50 \mathrm{~km}$ east of Auster. Of the 12 winter females 10 left the opening of the canyon for the western foraging area 2 to $3 \mathrm{~d}$ before the break-out. The remaining 2 females foraged in water, exposed by the break-out, directly over the continental shelf. One female (F-2) foraged at the junction of the canyon and the shelf slope before the break-out and after the break-out she moved south onto the shelf. The other female (F-9) left Auster for the ice edge after the others, travelled north-west (the others travelled northeast of Auster) and, upon reaching the sea, travelled east to the opening of the canyon in the eastern foraging area where she foraged for the remainder of her trip. During brooding (late July to September/October), male and female satellite-tracked penguins spent their entire time at sea in the eastern foraging area. Based on these movements, and the fact that in 1993 (when ice conditions in the eastern foraging area were similar to those in 1994) 2 females from Auster foraged only in the eastern area (Kirkwood \& Robertson 1997aj, it is possible that the eastern area, when free of fast-ice, would be preferred by the winter females over the more distant western foraging area. For adults at the brood-stage that must fatten and return to the colony within 14 to $20 \mathrm{~d}$ to fast and nourish their chick, it may not be energetically profitable to swim to the western area to forage. 
It is noteworthy that winter females using the western foraging area did not move soutkward into the polynya adjacent to the Taylor Glacier colony (see Fig. 1). This polynya is an annual feature of the Mawson coast and is the water entry and exit point for emperors at Taylor Glacier (3000 pairs). It is possible, but probably unlikely, that penguins from different colonies segregate at sea to avoid competition and potential depletion of prey stocks. If this were the case the Taylor Glacier birds may have drifted westward with the pack-ice (see below), as did those from Auster, for the polynya would probably be too small to sustain 3000 adults, particularly as it was avoided by adults from Auster. Another explanation may be that the pack-ice, when present, provides more options to foraging emperor penguins than a patch of open water flanked on 3 sides by fastice. In pack-ice the penguins can leave the water at any time and rest without having to cross extensive areas of open water as would be the case if they foraged in the polynya. Also, penguins in loose pack-ice can probably forage in any direction from numerous water entry and exit points whereas penguins residing on the flanks of a polynya may be forced to swim beneath fast-ice if they were to exploit the same foraging space as penguins in pack-ice.

\section{Foraging trip durations and distances travelled}

Foraging trip durations during winter are largely dependent on the 65 to $68 \mathrm{~d}$ (Prévost 1961) incubation stint by the male. The male is able to nourish the newly hatched chick for several days with an oesophageal secretion (Prévost 1961), thereby giving the female some flexibility in her return. At the Pointe Géologie colony $\left(66^{\circ} 40^{\prime} \mathrm{S} ; 140^{\circ} 01^{\prime} \mathrm{E}\right)$ females returned after 76 to 79 d away from the colony (Prévost 1961) whereas in our study, with the exception of 3 birds (see above), females returned to Auster after 67 to $96 \mathrm{~d}$ of absence.

The majority of females remained within $120 \mathrm{~km}$ of Auster, but they travelled up to $3100 \mathrm{~km}$ and averaged $2610 \mathrm{~km}$ in $77 \mathrm{~d}$ away, or $34 \mathrm{~km} \mathrm{~d}^{-1}$ (i.e $2610 \mathrm{~km} \div$ $77 \mathrm{~d})$. Occasionally penguins travelled in excess of $50 \mathrm{~km}$ in a single day and continued travelling during hours of darkness presumably looking for open water. In winter, only about $5 \%$ of the pack-ice is open water and newly formed leads may refreeze in $<2$ h (Ian Allison pers. comm.). Also, with potentially large numbers of birds in the eastern and western foraging areas (see below) it is possible that the distances recorded included avoidance of predators that may have been attracted by the high density of penguins.

The females' close proximity to Auster during winter was probably deliberate. Ocean currents sweeping westward along the Mawson coast may reach $3.6 \mathrm{~km}$ $\mathrm{h}^{-1}$ (Nunes Vaz \& Lennon 1996) and may move the pack-ice at, on average, $900 \mathrm{~m} \mathrm{~h}^{-1}$ (Allison 1989) or about $22 \mathrm{~km} \mathrm{~d}^{-1}$ At this average rate a female emperor drifting passively westward on ice floes would travel $1690 \mathrm{~km}$ (ie. $22 \mathrm{~km} \times 77 \mathrm{~d}$ ) from Auster, or 14 times the maximum $120 \mathrm{~km}$ for the majority of females. Even if the penguins drifted passively for half (39 d) their trip duration (leaving the other half for the return journey) they would have travelled about $850 \mathrm{~km}$ from the colony. Clearly it was advantageous for the females to remain within striking distance of Auster during their winter at sea.

There may be a number of reasons for this. First, the food may be spatially and temporally predictable with sufficiently high abundance and availability to satisfy the penguins energy requirements; adults may know this from previous experience. Second, adults may use bathymetric landmarks for hunting and navigation. Third, it may be energetically disadvantageous to travel, or drift on ice floes, far from the colony, particularly if the return journey was left until late in the foraging trip, which would require travel against the current and potential loss of fat reserves to be used in the forthcoming chick-brooding fast. It is noteworthy that the 2 females that made extended winter travels both lost mass while at sea. Fourth, it may be beneficial to the penguins to remain in a relatively small foraging area to minimise competition with penguins from other colonies, to huddle to reduce energy expenditure ( $R$. Kirkwood \& G. Robertson unpubl. data) and to reduce the risk of attack by predators

\section{Diving patterns in foraging areas}

South of the Antarctic Circle, only a few hours of twilight are experienced each day during mid-winter. Being visual predators (Wilson et al. 1993), it is not surprising that most dives by winter females occurred within the $6 \mathrm{~h}$ period of greatest light intensity, and were to less than $200 \mathrm{~m}$ depth; depths $>250 \mathrm{~m}$ were reached on only $3 \%$ of dives. These figures confirm those of Kirkwood \& Robertson (1997a) who described a similar distribution of dive depths amongst female emperor penguins foraging in winter.

Ninety percent of the females' diving day occurred during the $6 \mathrm{~h}$ period of greatest light intensity. Diving bouts were interspersed with short rest times lasting up to $20 \mathrm{~min}$. Females performed on average 27 foraging dives per day during which they caught an estimated $1.8 \mathrm{~kg} \mathrm{~d}$. With a catch rate averaging $67 \mathrm{~g}$ dive ${ }^{-1}$, the females consumed 1 to 2 Antarctic silverfish of mean mass $(51 \mathrm{~g})$, or $11 \mathrm{krill}$ of mean mass $(6 \mathrm{~g})$ per dive. 
The high proportion (81\%) of dives to less than $200 \mathrm{~m}$ of females and males $(64 \%)$ may be indicative of the distribution of prey in winter. The diet of the females was dominated by juvenile Antarctic silverfish (72\% by mass), squid (Psychroteuthris glacialis: 16\%) and krill $(12 \%)$ while that of the brood-stage males was dominated by juvenile silverfish $(53 \%)$, krill $(43 \%)$ and squid ( $2 \%$ ). Since juveniles of fish and squid occur in the upper $(<200 \mathrm{~m})$ part of the water column it is likely that these prey types were encountered by female penguins on the majority of their foraging dives. The high proportion (43\%) of krill in the diet of the males and the high incidence $(36 \%)$ of deep dives $(>200 \mathrm{~m})$ may be indicative of krill deep in the water column in winter.

\section{Total prey consumption in foraging areas}

The size of the foraging area and its location, the diet composition and prey harvest rates of female emperors provided indirect evidence of the location and occurrence of prey near Auster in winter. About $50 \%$ of foraging days by winter females were spent in only $15 \%\left(1700 \mathrm{~km}^{2}\right)$ of the total foraging area.
Assuming that the non-instrumented females at Auster also hunted in this area then the density of females in the eastern and western foraging areas may have, at times, reached about 1 bird per $130 \mathrm{~m}^{2}$ (ie. $1700 \div 13400$ females). In $77 \mathrm{~d}$ away, females consumed about $109 \pm 14 \mathrm{~kg}$ of prey (i.e. $1.8 \mathrm{~kg}$ in each of 63 foraging days) which is equivalent to about $1520 \mathrm{t}$ for all females at Auster The females achieved this rate of prey intake by averaging only 27 dives per day ( 5 dives per hour for a $6 \mathrm{~h}$ day). Also, they not only met their energy requirements but added 2.2 to $5.6 \mathrm{~kg}$ mass while at sea, suggesting that prey stocks were not seriously depleted by the penguins. These are remarkable estimates particularly in light of the potential density of birds in the eastern and western foraging areas and that about half (760 t) of the total estimated prey consumption by Auster females may have occurred in only a $1700 \mathrm{~km}^{2}$ area (i.e. $60 \times$ $28 \mathrm{~km}$ ). It would be useful to know if the emperor penguins from Auster use these areas annually and to study their physical and biological properties in order to understand their capacity to sustain the potential prey harvest rates mentioned above. The estimates above attest to the occurrence of prey species in these 2 areas of the Mawson coast in winter.

Appendix 1. Aptenodytes forsteri. Body mass, HTO (tritiated water) blood levels (expressed as counts per minute (cpm) in a liquid scintillation counter] and water influx rates of emperor penguins from Auster in 1994. Background activity was $\sim 15 \mathrm{cpm}$

\begin{tabular}{|c|c|c|c|c|c|c|}
\hline \multirow[t]{2}{*}{ Penguin } & \multirow{2}{*}{$\begin{array}{c}\text { Departure mass } \\
(\mathrm{kg})\end{array}$} & \multirow{2}{*}{$\begin{array}{l}\text { Return mass } \\
\qquad(\mathrm{kg})\end{array}$} & \multirow{2}{*}{$\begin{array}{l}\text { Time away } \\
\text { (d) }\end{array}$} & \multicolumn{2}{|c|}{ HTO level $(\mathrm{cpm})$} & \multirow{2}{*}{$\begin{array}{l}\text { Water influx } \\
\left(\mathrm{ml} \mathrm{kg} \mathrm{kg}^{-1} \mathrm{~d}^{-1}\right)\end{array}$} \\
\hline & & & & On departure & On return & \\
\hline \multicolumn{7}{|l|}{ Females } \\
\hline$F-2$ & 26.5 & 29.0 & 69 & 39108 & 99 & 45.16 \\
\hline$F-3$ & 31.0 & 33.2 & 76 & 32198 & 74 & 43.27 \\
\hline$F-4$ & 24.0 & 28.5 & 69 & 42453 & 69 & 49.25 \\
\hline$F-5$ & 27.5 & 28.5 & 67 & 36214 & 45 & 54.19 \\
\hline F-6 & 24.4 & 28.0 & 81 & 40164 & 52 & 58.90 \\
\hline $\mathrm{F}-8$ & 24.2 & 28.0 & 81 & 30164 & 45 & 45.18 \\
\hline$F-9$ & 24.4 & 30.1 & 71 & 40032 & 56 & 48.78 \\
\hline$F-10$ & 22.4 & 24.5 & $72^{d}$ & 44195 & 43 & \\
\hline $\mathrm{F}-12$ & 25.0 & 28.8 & 96 & 35744 & 48 & 41.58 \\
\hline $\mathrm{F}-14$ & 23.0 & 27.5 & 82 & 44083 & 55 & 43.35 \\
\hline F-16 & 22.4 & 26.8 & 80 & 45566 & 45 & 45.68 \\
\hline$F-18$ & 25.8 & 30.0 & 74 & 36385 & 56 & 50.29 \\
\hline$F-20$ & 28.2 & 35.5 & $102^{b}$ & & & \\
\hline$F-25$ & 26.0 & 32.0 & 80 & 36993 & 50 & 46.24 \\
\hline \multicolumn{7}{|l|}{ Males } \\
\hline $\mathrm{M}-1$ & 23.5 & 24.0 & 29 & 27369 & 148 & 118.91 \\
\hline$M-2$ & 23.0 & 31.0 & $55^{c}$ & 24010 & 70 & \\
\hline M-3 & 23.8 & 29.0 & $55^{c}$ & 29137 & 100 & \\
\hline$M-4$ & 24.0 & 29.0 & 21 & 33760 & 748 & 94.82 \\
\hline$M-5$ & 23.1 & 29.5 & 15 & 30243 & 1750 & 114.94 \\
\hline$M-6$ & 22.5 & 27.3 & 37 & 36017 & 535 & 59.46 \\
\hline M-7 & 24.5 & 29.0 & $48^{b}$ & 32695 & 47 & \\
\hline$M-8$ & 24.0 & 28.5 & 19 & 33343 & 443 & 120.43 \\
\hline M-9 & 24.0 & 24.1 & 32 & 33069 & 694 & 64.62 \\
\hline M-10 & 23.5 & 24.0 & 29 & 28186 & 1142 & 70.89 \\
\hline$M-11$ & 25.0 & 26.0 & $61^{\mathrm{c}}$ & 35425 & 65 & \\
\hline
\end{tabular}


forsteri at two Mawson Coast colones, Antarctica. Ibis $136: 19-31$

Schmidt-Nielsen K (1975) Animal physiology: adaptations and environment. Cambridge University Press, Cambridge

Suter W. Morel P (1996) Pellet analysis in the assessment of Great Cormorant Phalacrocorax carbo diet: reducing biases from otolith wear when reconstructing fish length. Colon Waterbirds 19:280-284

van Heezik Y, Seddon P (1989) Stomach sampling in the yellow-eyed penguin: erosion of otoliths and squid beaks. J Field Ornithol 60:451-458

Editorial responsibility: Otto Kinne (Editor),

Oldendort/Luhe, Germany
Williams R, McEldowney A (1990) A guide to the fish otoliths from waters off the Australian Antarctic Territory, Heard and Macquarie Islands. ANARE (Aust Nat Antarct Res Exped) Res Notes 75:1-173

Wilson RP (1984) An improved stomach pump for penguins and other seabirds. J Field Ornithol 55:109-112

Wilson RP, Pütz K, Bost CA, Culik BM, Bannasch R, Reins T, Adelung D (1993) Diel dive depth in penguins in relation to diet vertical migration of prey: whose dinner by candlelight? Mar Ecol Prog Ser 94:101-104

Zar JH (1984) Biostatistıcal analysis, 2nd edn. Prentice-Hall International, Englewood Cliffs, NJ

Submitted: April 11, 1997; Accepted: August 25, 1997

Proofs received from author(s): November 5, 1997 